\title{
Primary culture of insect midgut cells
}

\author{
Raziel S. Hakim • Silvia Caccia • Marcia Loeb • \\ Guy Smagghe
}

Published online: 23 May 2009

(C) The Society for In Vitro Biology 2009

\section{Erratum to: In Vitro Cell.Dev.Biol.-Animal DOI 10.1007/s11626-009-9176-7}

On page 2, right-hand column, insert the following paragraph before the heading Procedure.

Culture medium.

$200 \mathrm{ml}$ Grace's medium, $14 \mathrm{ml}$ FBS, $0.2 \mathrm{~g}$ Yeastolate, 0.1 to $0.5 \%$ gentamicin (Sigma), $1.2 \mathrm{ml}$ vitamin mixture, $0.02 \%$ antibiotic-antimycotic solution $1 \mathrm{X}, 1 \mathrm{ng} / \mu \mathrm{l} 20-\mathrm{OH}-\mathrm{E}$, and $10 \mu 1 / \mathrm{ml}$ FBX or alternatively $100 \mathrm{ng} / \mathrm{ml}$ arylphorin.

The online version of the original article can be found at http://dx.doi. org/10.1007/s11626-009-9176-7.

R. S. Hakim $(\bowtie)$

Department of Anatomy, College of Medicine,

Howard University,

520 W. St NW,

Washington, DC 20059, USA

e-mail: rhakim@mac.com

S. Caccia $\cdot$ G. Smagghe

Laboratory of Agrozoology, Department of Crop Protection,

Faculty of Bioscience Engineering, Ghent University,

9000 Ghent, Belgium

M. Loeb

Insect Biocontrol Laboratory, USDA-ARS,

Beltsville, MD 20705-2350, USA

Present Address:

S. Caccia

Departament de Genètica, Facultat de Ciències Biològiques,

Campus de Burjassot, Universitat de València,

46100 Valencia, Spain 